Vertebrate Zoology, whose collection forms the core of the group's website.

Wake, the driving force behind the website, said the long-term goal is to develop a page for each of the nearly 5,000 species of frogs, toads, newts, salamanders and caecilians (burrowing, wormlike amphibians).

"The release of amphibiaweb.org is a plea for volunteers," says Wake. "If scientists see a species missing, help us start a page."

After six years as chairman of the task force, Ron Heyer, curator of amphibians and reptiles at the National Museum of Natural History in Washington, is stepping down this spring. His successor is expected to be James Hanken, professor of organismic and evolutionary biology at Harvard University and herpetology curator at the university's Museum of Comparative Zoology.

Balloting began last week on Hanken's appointment. The handover of responsibilities is expected to take place in June, when scientists meet in La Paz, Mexico, for the annual conference of the American Society of Ichthyologists and Herpetologists and other organizations.

Reflecting on his tenure, Heyer says that the most important point was that "a consensus was reached that in fact the amphibian population decline and disappearance phenomenon is real."

There was debate about whether the decline was a cyclical downturn, he says, but studies have convinced amphibian biologists that "something catastrophic was happening".

A reflection of the growing interest in amphibian studies is a $\$ 3$ million National Science Foundation grant to 21 investigators last autumn. Headed by James Collins, chair of biology at Arizona State University, the three-year international project will examine the role of host-pathogen biology in the decline of amphibians. Collins says that biologists "not accustomed to big science" projects will be involved in a study involving fields from molecular immunology to global climate change.

"If they answer the research questions they are asking," says Heyer, "they will give us all the information we need to determine where disease fits in to the amphibian picture."

There will be a session on amphibian decline at this month's annual meeting of the American Association for the Advancement of Science in Washington.

One study at the meeting will report the discovery of chytrid fungus in salamanders in Arizona. The chytrid fungus is known to kill frogs, and may be one cause of the worldwide decline in frog populations. Rex Dalton

\title{
Anderson steps down from Wellcome over Oxford row
}

London

The controversy surrounding Oxford zoology professor Roy Anderson deepened last week with the news that he has stepped down temporarily from his responsibilities as governor of the Wellcome Trust. This follows Anderson's recent suspension on full pay from his Oxford post - and his directorship of the Wellcome Centre for the Epidemiology of Infectious Diseases pending disciplinary hearings.

It has now emerged that three formal complaints have been made against Anderson concerning his alleged attempts to influence a decision by a zoology department appointments committee, which he was chairing, for a readership in epidemiology (see Nature 403, 353; 2000).

The complaint by the successful candidate, Sunetra Gupta, came to prominence when remarks made by Anderson became public and she filed a complaint through a solicitor late last year. Angela McLean of the Biotechnology and Biological Sciences Research Council's Institute for Animal Health has also filed a complaint through a solicitor. The third complaint was made by a senior researcher in the department.

The complaints form part of inquiries into Anderson's behaviour both outside and during an appointments committee in September last year. If convened, Oxford's Visitatorial
Board - the five dons who will lead the disciplinary hearing - would also consider written evidence from members of the committee.

The Wellcome Trust says Anderson offered to step down temporarily from his

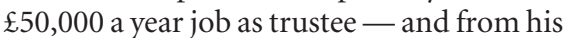
responsibilities on the three Wellcome Trust advisory panels that he works on - because of formal proceedings against him. Mike Dexter, director of the trust, says he does not know the number of complaints against Anderson or their basis. "It was his wish not to take part in any decisions [at the trust], which I think is honourable," says Dexter.

Dexter says Anderson's action is entirely related to the formal complaints, and that the trust is not pursuing any kind of investigation of its own. He refuses to speculate on whether such an investigation might follow, although he does not rule it out.

"It's an Oxford matter at the present," says Dexter. "It would be most unfair and unfortunate if we were to intervene at any stage. Roy's a brilliant scientist, a wonderful servant of the trust, and we simply allow the process to continue."

The appointments committee voted six out of eight in favour of Gupta. Her candidacy was supported by Sir Robert May, another professor in the department and the government's chief scientific adviser and head of the Office of Science and Technology. Natasha Loder

\section{Nossal named Australian of the Year}

\section{Sydney}

Sir Gustav Nossal, a leading immunologist and former president of the Australian Academy of Science, has been appointed Australian of the Year, an honorary post that nevertheless provides a platform for advocacy.

On the announcement of his appointment by the prime minister, John Howard, Nossal declared three issues he would pursue: increased public investment in universities and research (especially in medicine); improvements in the health of Australian Aborigines; and reconciliation between Aborigines and other Australians on social issues, particularly land rights.

Aborigines suffer much higher disease and mortality than most Australians. The Aboriginal community is demanding an apology for the damage to their society since European settlement began in 1788 .

Nossal's appointment enhances his influence as deputy chairman of the Council for

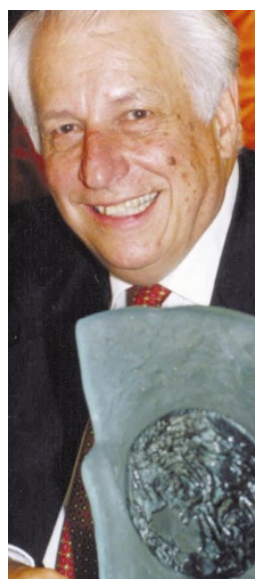

Nossal: will promote health of Aborigines.
Aboriginal Reconciliation, charged with producing a declaration and initiating action acceptable to both sides. Howard has been attacked for being slow to respond to Aboriginal protests. Nossal expects Aborigines to disrupt the Olympic Games in Sydney.

Peter Doherty, another immunologist and former Australian of the Year, who won the award after sharing the Nobel Prize for Physiology or Medicine in 1996, used his term to advocate increased funding for medical research. The government approved a major increase last year (see Nature 399, 94; 1999). Peter Pockley 